\title{
PM Motors for Hybrid Electric Vehicles
}

\author{
Massimo Barcaro ${ }^{*}, 1$, Nicola Bianchi ${ }^{1}$ and Freddy Magnussen ${ }^{2}$ \\ ${ }^{I}$ Electric Drive Laboratory, Department of Electrical Engineering, University of Padova, via Gradenigo 6/A, 35131 \\ Padova, Italy \\ ${ }^{2}$ ABB Corporate Research, Forskargränd 6, Västerås, 72178, Sweden
}

\begin{abstract}
The global warming has become a very important issue during the last decade. The worldwide research is oriented to obtain efficiency improvements on energy consuming and sustainable energy sources utilization. Hybrid electric vehicles (HEV) are able to achieve this goal. In addition the utilization of high efficiency electric machines, using high energy permanent magnet, allows an increased reduction of fuel consumption and exhaust gas emissions. This paper deals about various topologies of the permanent magnet machines and some commercial vehicles adopting these motors are described.
\end{abstract}

Keywords: Hybrid electric vehicle, permanent magnet motor.

\section{INTRODUCTION}

Increasing awareness of air quality and interest in innovative vehicles stimulate the research activity to improve the propulsion systems by reducing the vehicle emissions. Hybrid electric vehicles (HEVs) appear as the nearest forced first step in order to have reductions in both emissions as well as fuel consumption. In fact HEVs have attracted their fair share of attention from automakers worldwide and so on [1]. The HEV is a vehicle that has two or more energy sources, but in the common use HEV means that the vehicle has a propulsion due to both an Internal Combustion Engine (ICE) and an electrical machine, while the energy source are fuel and batteries. HEVs are able to achieve high performance by combining high-energy density combustible, with high efficiency of electric-drive systems. Moreover, the torque generated by the vehicle by the electric motor can be appropriately controlled so that the vehicle stability and safety are greatly improved.

Considerable improvements have been obtained in all studying area of HEVs due to the efficiency enhancement of both electrical machines and internal combustion motors. The latter issues refers to the adoption of the Atkinson cycle ICE.

High relevance has the improvement of the energy storage system. Now the most promising battery technology to power these vehicles is the Lithium Ion (Li-ion) battery, though the Nickel Metal Hydride (NiMH) are the most utilized battery in commercial applications. Its high cost its is still a drawback and accounts for the continuing presence as NiMH batteries in the market.

The batteries are devices with high specific energy, while when a peak power is required a specific power density

*Address correspondence to this author at the Electric Drive Laboratory, Department of Electrical Engineering, University of Padova, via Gradenigo 6/A, 35131 Padova, Italy; Tel: 0039049827 7590; Fax: 0039049827 7599; E-mail: massimo.barcaro@unipd.it device could be very useful. The use of ultracapacitors has a high potential in the HEVs. Ultracapacitors [2] have the advantage of being a more robust power device when compared to batteries, as example during regenerative braking that is considered to be a high-power event. On the other side another hypothetical storage system could be the flywheels [3]. Each system has advantages or drawbacks according to the way in which the energy is stored: electrochemical for batteries, electrostatical for ultracapacitors and mechanical for flywheels.

\section{HYBRID ELECTRIC VEHICLES ARCHITECTURE}

The major challenges for HEV design are managing multiple energy source, highly dependant of driving cycles, battery sizing and battery management. The architecture of a hybrid vehicle is usually defined as the connection between the components of the vehicle traction, and then the energy flow path [4]. Recently, with the introduction of some new features and improvements, the extended classification of $\mathrm{HEV}$ is:

Series Hybrid: the traction power is delivered by the electric motor, while the ICE, via a generator, produces electric power to drive the electric motor [5]. The excess power is then stored in the battery pack. The ICE is decoupled from the driven wheels and can be operated mostly in the maximum efficiency region. The major shortcomings of a series hybrid drive train configuration are the high power installed in each component and the request of a generator. In fact the energy from the ICE is converter twice before to drive the wheels (Fig. 1). Thus the system is more expensive than the parallel one.

Parallel Hybrid: there is direct mechanical connection between the hybrid power unit and the wheels. In addition, this layout has an electric traction motor that drives the wheels, and can recuperate a share of the braking energy, in order to charge the batteries (regenerative braking) or help the ICE during the acceleration conditions. In fact ICE and electrical motor are coupled by a mechanical device (Fig. 2). 


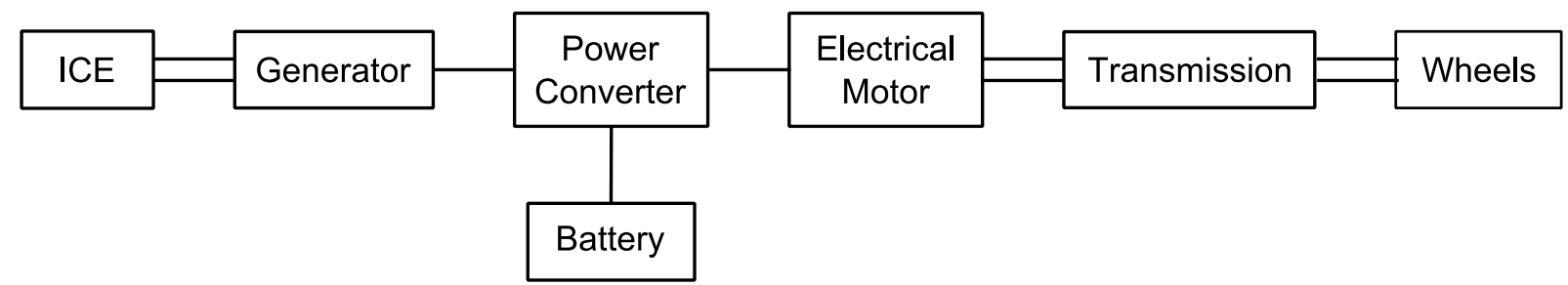

Fig. (1). Series hybrid architecture.

Then the electrical machine can be designed with a reduced capability, i.e. cost and volume. There are several configurations depending on the structure of the mechanical combination between the ICE and the electrical motor. In fact there can be a torque-coupling with single-shaft or twoshaft configuration, a speed-coupling with planetary gear unit, a merge of both previous coupling.

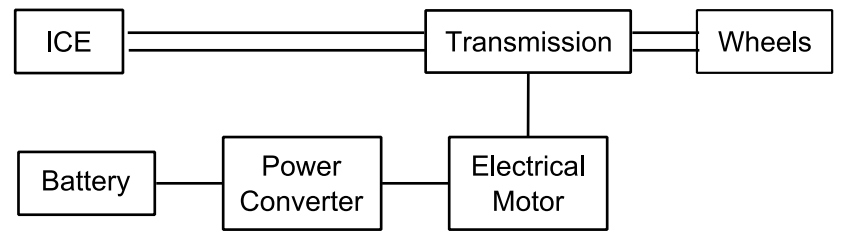

Fig. (2). Parallel hybrid architecture.

Series-Parallel Hybrid: the series layout and the parallel layout are merged together in order to have both advantages (Fig. 3). In particular the ICE is able to supply the electrical motor or charge the battery thanks to a generator.

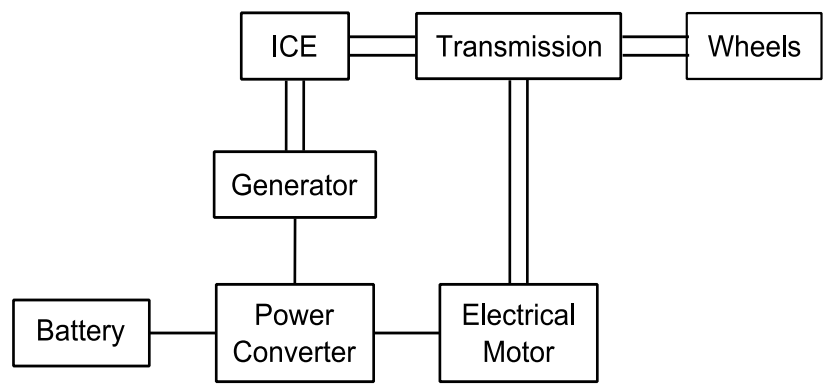

Fig. (3). Series-parallel hybrid architecture.

Complex Hybrid: there are two separate mechanical links obtaining a light transmission system and a flexible mounting. As an example, the front wheels are powered by an hybrid propulsion, while the rear wheels has a pure electric system. There is a wi deflexibility on the power flux managing.

Moreover, the general hybrid electric vehicle can be classified depending on the relevance of the power and function electric machines, as reported in Table $\mathbf{1}[4,27]$.

Thus, the micro hybrid could allow to start-stop and partly regeneration (in particular often called integratedstarter alternator), while the mild hybrid and the full hybrid could supply a high share or the whole power drive. Concerning the micro hybrid, the vehicle could have a parallel layout or a series-parallel layout.

\section{PM MACHINE TOPOLOGIES}

Permanent magnet (PM) synchronous machines have found wide applications in various fields. Drive systems based on PM represent a competitive solution for actual performance automotive and naval applications [7]. Compared to other electrical machines, PM machines combine the advantages of high efficiency, power factor and torque density, high overload capability, robustness, reduced maintenance, compactness and low weight [8]. High energy PM exciting allows to reduce overall volume (i.e. weight) and stator losses. On the other hand, the absence of rotor copper losses allows a further increase of the efficiency. Also fault-tolerant capability [9], flux-weakening capability $[10,11]$, and low short-circuit current could be obtained. Thanks to these features the PM machine becomes wellsuited to the traction requirements [12-15].

Table 1. Hybrids Classification

\begin{tabular}{|l|c|c|c|}
\hline & Micro & Mild & Full \\
\hline \hline Power (kW) & 2,5 & $10-20$ & $30-50$ \\
\hline Voltage level (V) & 12 & $100-200$ & $200-300$ \\
\hline Energy saving (\%) & $5-10$ & $20-30$ & $30-50$ \\
\hline Price increase (\%) & 3 & $20-30$ & $30-40$ \\
\hline
\end{tabular}

Although the PM excitation has some drawbacks, such as cost of the permanent magnets, risk of demagnetization at high temperature, additional control effort; the technical advantages of the PM motor have yielded the extension of their area of application in the last years.

\section{A. SPM Motors}

Among the others, the Surface-mounted PM (SPM) motors are mainly used. The reason is due to flexibility and facility of building, the quickly and well-known design methodology. The main drawback of this solution is the very limited constant power speed region (CPSR) if any suitable method is adopted [16].

Fig. (4a) shows the rotor of an SPM motor, designed for the propulsion of a catamaran, after the PM assembling and before the applying of a plastic retaining layer [17].

\section{Fractional-Slot Stator}

The fractional-slot winding allows to reduce the length of the end-winding. Consequently the Joule losses (i.e. the phase resistance), the whole volume (i.e. the weight) are 
reduced, and the efficiency is improved as respect to conventional winding of ac machine. Fig. (4b) shows the detail of the end-winding of a 12-slot 8-pole fractional-slot winding. The selection of the correct number number of slots and poles is particularly important [18].

(a)

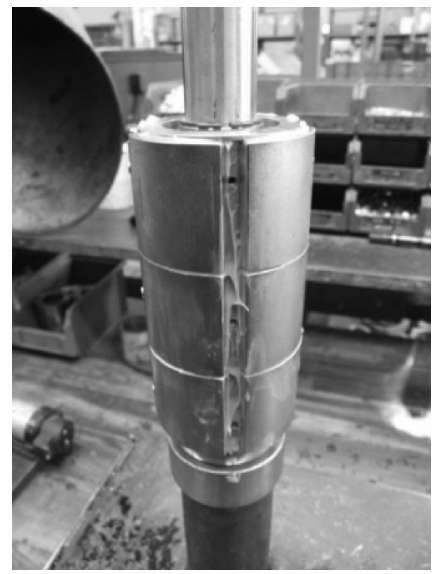

(b)

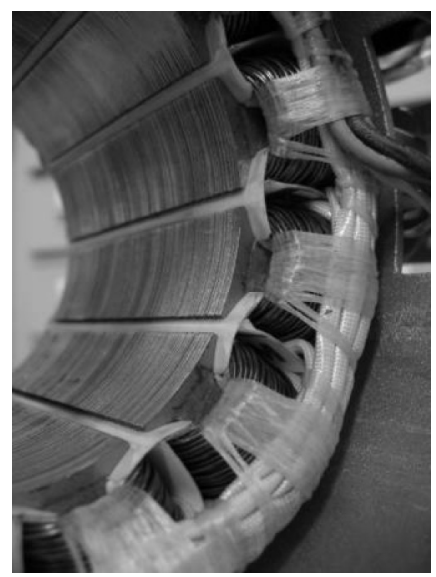

Fig. (4). SPM motor for propulsion system: (a) the 4-pole rotor, (b) detail of a 12-slot 8-pole fractional-slot winding.

\section{External Rotor Motors}

The geometry of the SPM motor is well-suitable for the external-rotor. Such a machine is a proper topology for inwheel traction applications, because the rotor is directly coupled to the wheel. Moreover this solution requires a low back-iron length. A high diameter at the air gap and a high torque per volume ratio can be obtained.

Fig. (5a) shows the external rotor of an integrated-starter alternator (ISA) while Fig. (5b) shows a detail of the nonoverlapping winding of the same motor.

\section{B. IPM Motors}

The internal permanent magnet (IPM) motor has the PMs buried into the rotor. They are more protected to demagnetization due to the stator current as respect of the SPMs, with a benefit for overload capability and safety. The new hybrid vehicles mount increasingly this motor topology, thanks to their well-know advantages $[14,19]$.
The lamination of the rotor can be designed in order to have, in addition to the torque component due to the PM, a torque component due to the anisotropy of the rotor. The difference between the reluctance of $d$-axis and $q$-axis is reached thanks to an accurate design of the flux barriers (see Fig. 6).

(a)

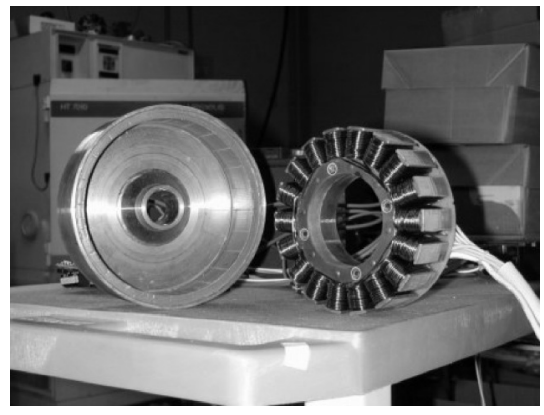

(b)

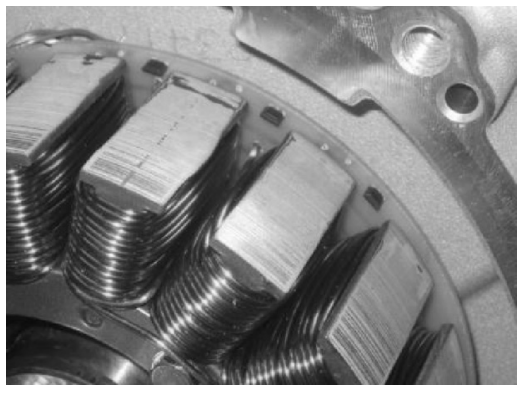

Fig. (5). SPM motor with external rotor: (a) whole motor (b) detail of non-overlapping coils.

The torque density is usually higher than that of SPM motor. The reluctance torque component allows to obtain a good CPSR with a suitable flux-weakening control [20]. Fig. 6 shows the lamination of a 12-slot 8-pole machine used for an ISA [21].

(a)

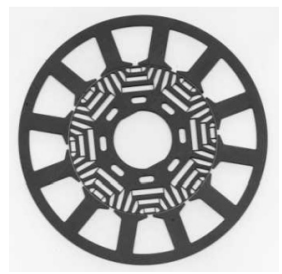

(b)

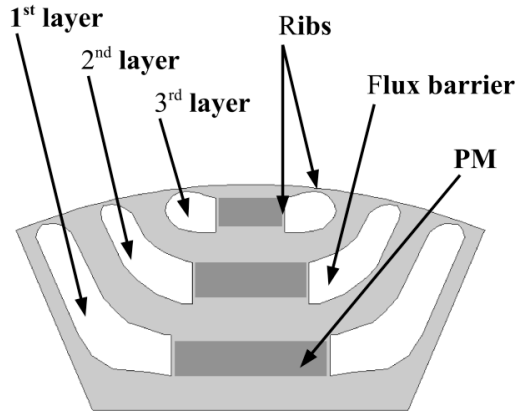

Fig. (6). IPM motor: (a) lamination of a 12-slot 8-pole machine, (b) rotor pole design. 
(a)

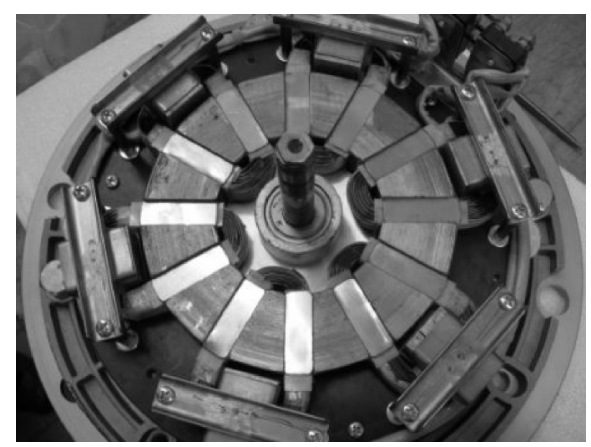

(b)

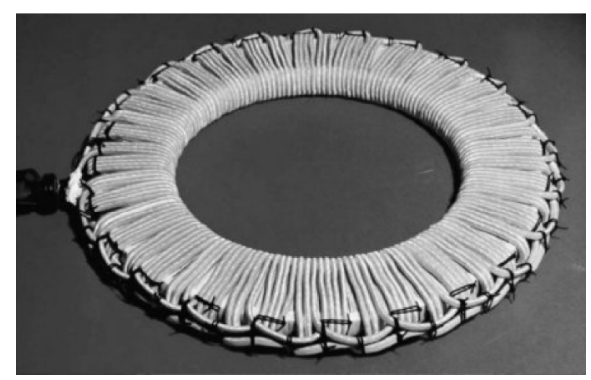

Fig. (7). Axial SPM motors: (a) single-side stator with additional inductance coils (b) double-side stator winding.

\section{Axial-Flux Motors}

Even if axial flux disc type permanent magnet (AFPM) machine is the more suitable motor type for an in-wheel design [22], it is not yet popular in the commercial solution.

These AFPM machines may be classified as single-sided, double-sided or multistage (multidisc) machine. The singlesided machine has one stator and one rotor while the doublesided machine could have an internal rotor and two external stators or a reverse configuration. Unlike general radial flux machine, the AFPM machines could be easily designed with slotted or slotless stator. Typically these machines have SPM rotors. The drawbacks are the same of the SPM radial-flux motor. In addition there are complications due to the presence of a high attractive axial force. The advantages are essentially linked to the possibility to have very high torque density with a in-wheel design.

Fig. (7a) shows an axial single-sided stator with fractional-slot non-overlapped coils and additional leakage inductances used to extend CPSR [23]. Fig. (7b) shows the internal slotless stator (with Litz wire winding) of a doubleside machine [24].

\section{COMMERCIAL APPLICATIONS}

The selling trend of HEVs of U.S. seems to have an rapid increasing: $17 \mathrm{HEVs}$ sold in 1999, 88.000 in 2004, 256.800 in 2006. The outlooks are that there will be as many as 65 hybrid models (28 cars and 37 light trucks) in the market by 2010, with sales expected to reach nearly 775.000 units [4], or $4.6 \%$ of the total U.S. new light-vehicle market.

\section{A. Toyota Prius}

Toyota has started to study HEVs earlier than the first appear of Prius in the Japanese market in 1997. The Toyota
Prius (2003) was the first full-hybrid vehicle in the word. It allows a complete electric traction, a regenerative brake and an automatic preferring use of the energy stored in the battery. There is a planetary differential gear/power split interface device that allows the mechanical coupling. The Prius adopts a series-parallel architecture (see Fig. 8) [25], and has two IPM machines coupled to the ICE $(1.5 \mathrm{~L} 76$ HP).

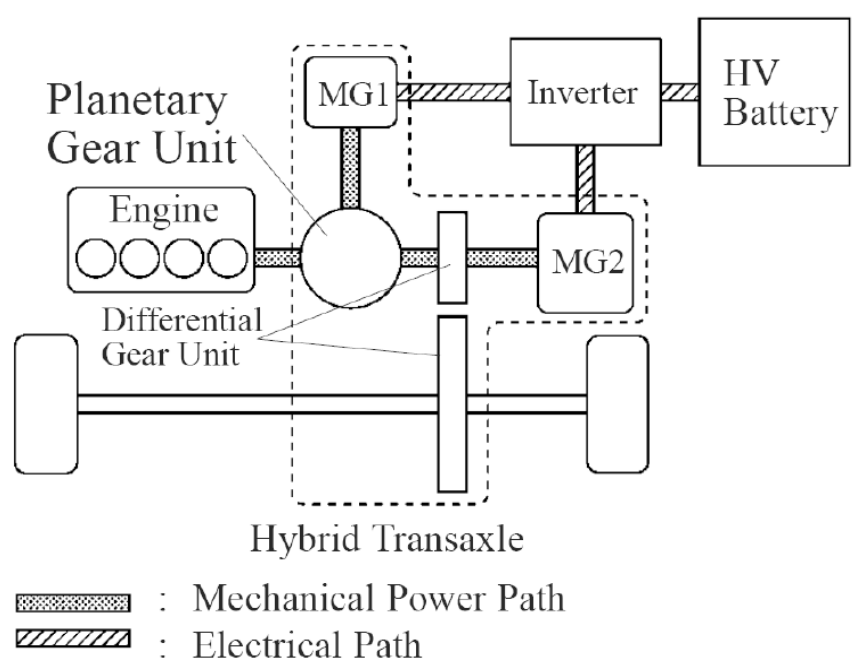

Fig. (8). Series-parallel hybrid architecture of Toyota Prius.

Both machines can be motor and generator. The first (MG1) has to recharge the battery, to start the ICE and to supply power to the second PM machine (MG2) that has to do the regenerative brake and to drive the wheel. Both machines are water-cooled and the power are $28 \mathrm{~kW}$ and 50 $\mathrm{kW}$ respectively, with a maximum voltage equal to $500 \mathrm{~V}$ ac. Moreover, the PMs of the latter machine are buried in the rotor adopting a $\mathrm{V}$-shape structure.

As respect to the previous model of Prius the most important improvement is introduction of a boost converter. The previous Prius model had a $273.6 \mathrm{~V}$ dc bus voltage of both inverter and batteries: in the new system the boost converter adjust the voltage between batteries $(201.6 \mathrm{~V} \mathrm{dc})$ and the IPM machines $(500 \mathrm{~V} \mathrm{dc})$. This innovation has involved an improvement of the power to weight ratio. The $\mathrm{NiMH}$ battery consists of 168 cells with a power of $21 \mathrm{~kW}$ [25].

Considering a medium utilization cycle, the consumption is about 4.3 litres every $100 \mathrm{~km}$ with carbon dioxide emissions of $104 \mathrm{~g} / \mathrm{km}$, that is $50 \%$ less than an equivalent turbo-diesel engine [29].

\section{B. Toyota SUV Models}

The Toyota Highlander is a Sport-Utility vehicle (SUV) with 4-wheel drive. The hybrid system is slightly more complex than Prius, thanks to the bigger dimensions and the higher performance required (see Fig. 9 [26, 27]).

The ICE is a $3.3 \mathrm{~L} 208 \mathrm{HP}$, while a $123 \mathrm{~kW}$ PM machine drives the front wheels and a $50 \mathrm{~kW}$ PM machine drives the rear wheels. The system is provided of the same $28 \mathrm{~kW} \mathrm{PM}$ alternator. The NiMH battery has a $45 \mathrm{~kW}$ power and a nominal voltage equal to $288 \mathrm{~V}$ dc. The efficiency of the overall system is improved with a $650 \mathrm{~V}$ dc supplied by a 
boost converter. The volumetric power density of the control unit (including inverters and boost) is improved about $80 \%$ in comparison with Prius [26].

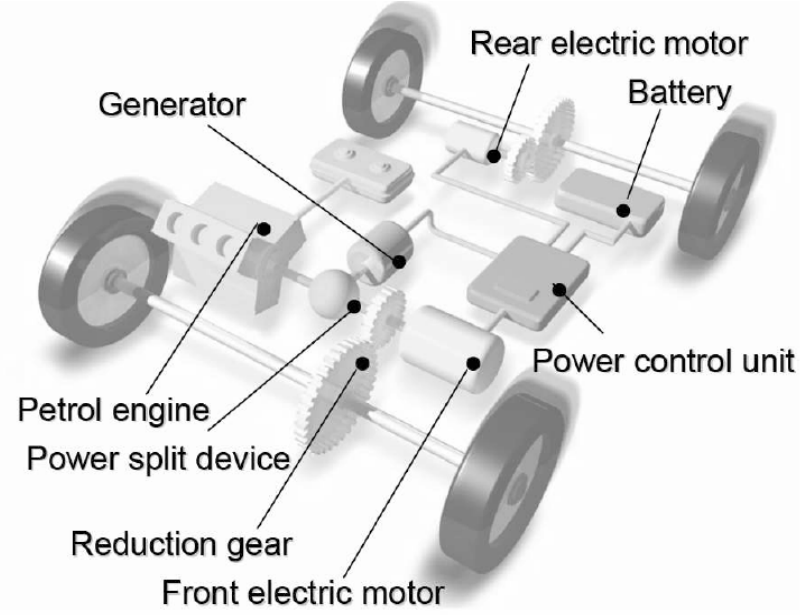

Fig. (9). Toyota Highlander architecture layout.

Also the Lexus RX400h has the same hybrid system of the Toyota Highlander (Fig. 10). Instead the Lexus GS450h has an improved hybrid system. The electrical machines have always PM rotor and a water/oil-cooling system. The machine MG1 has nominal power of $134 \mathrm{~kW}(180 \mathrm{HP})$ at $13000 \mathrm{rpm}$. The machine MG2, the drive motor, has a continuous power equal to $147 \mathrm{~kW}$ and a maxium starting torque equal to $275 \mathrm{Nm}$ up to $3840 \mathrm{rpm}$. It should be noted that the rated power to volume ratio of whole hybrid system is three times higher as respect to Prius, and less than two times regarding the Highlander.

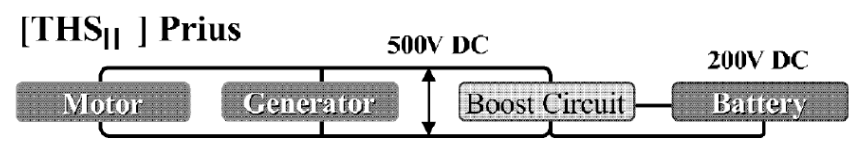

\section{$\left[\mathrm{THS}_{||}\right]$RX400h}

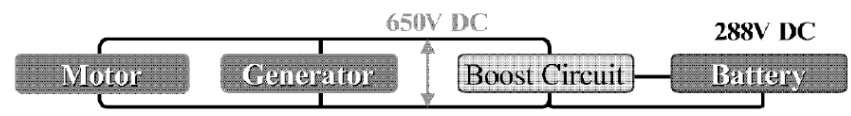

Fig. (10). Toyota Hybrid System (THS) for Toyota Prius and Lexus RX400h.

\section{Honda Civic}

The new Honda Civic Hybrid has considerably improved the performance, as respect to the old models, thanks to a reached high torque at low speed. When ICE and electric motor works together the Civic Hybrid, (Fig. 11), is able to perform $85 \mathrm{~kW}$ at $6000 \mathrm{rpm}$ with a maximum torque equal to $170 \mathrm{Nm}$ at $2000 \mathrm{rpm}$, with a parallel hybrid architecture.

The ICE has a power of $70 \mathrm{~kW}$ at $6000 \mathrm{rpm}$ with a torque equal to $123 \mathrm{Nm}$ at $4500 \mathrm{rpm}$. The PM synchronous threephase motor can supply $14.6 \mathrm{~kW}$ at $2000 \mathrm{rpm}$ (103 Nm up to $1160 \mathrm{rpm}$ ). The storage system consists of $22 \mathrm{NiMH}$ battery with a rated capacity of $5.5 \mathrm{Ah}$ and a voltage of $158.4 \mathrm{~V}$ (that is the same of the electrical motor). (a)

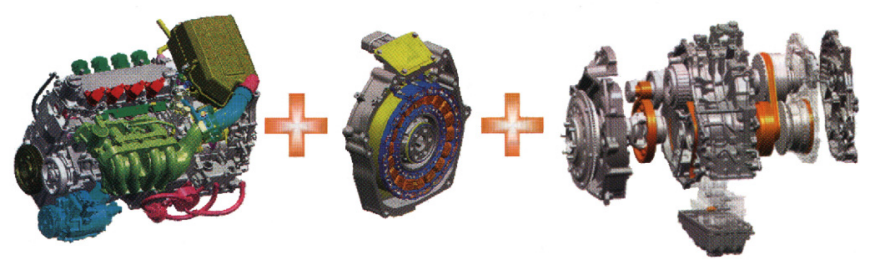

(b)

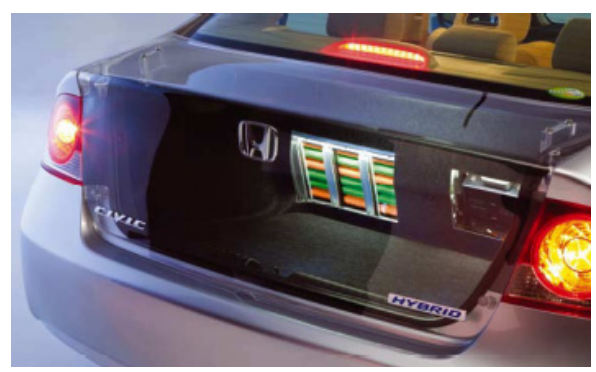

Fig. (11). Honda Civic Hybrid: (a) propulsion components (ICE, electric motor, gear box), (b) position of the battery.

\section{Peugeut Citroën (PSA) Group}

The PSA group has developed two prototypes: Peugeout 307 Hybrid HDi and Citroën C4 hybrid HDi (Fig. 12). It should be noted that usually the hybrid system uses a gasoline ICE while the PSA group engineers have focused on the diesel ICE. The prototypes performance are about $29.41 \mathrm{~km} /$ litre and a carbon dioxide emissions of $90 \mathrm{~g} / \mathrm{km}$, considering a $1.6 \mathrm{~L} 66 \mathrm{~kW}$ diesel engine (with a automatic robotic 6-gear box) and a $16 \mathrm{~kW}$ electrical motor. The hybrid system has a parallel architecture. The electrical machine has a nominal torque of $80 \mathrm{Nm}$ but can overloaded up to $23 \mathrm{~kW}$ and $130 \mathrm{Nm}$. The electrical machine is a PM synchronous motor that can be supplied with an ac variable voltage from $210 \mathrm{~V}$ to $380 \mathrm{~V}$. The 240 -unit NiMH battery can exchange $23 \mathrm{~kW}$ with the inverter at $288 \mathrm{~V} \mathrm{dc}$.

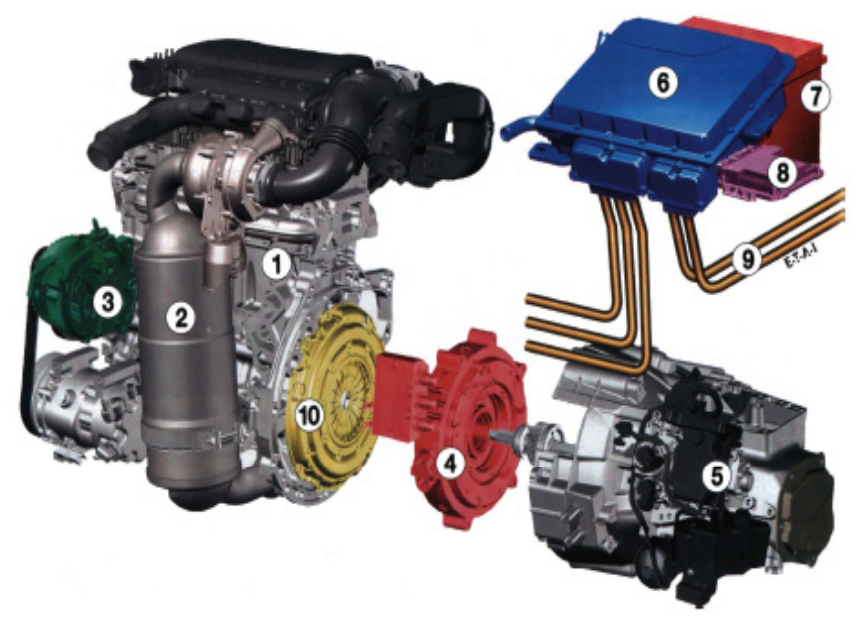

Fig. (12). PSA hybrid system componets: (1) diesel engine, emissions filter, (2) Start\&Stop system, (3) electrical PM motor, (4) robotic gear box, (5) inverter and rectifier, (6) 12-Volt battery, (7) managing system, (9) electrical cable, (10) clunch. 


\section{E. Others Models and the Ethanol Way}

The General Motor (GM) BioPower hybrid system couples an alternative fuel (i.e. E85 ethanol) with an electric propulsion. The GM layout is called two-mode hybrid system because the transmission splits up into two modes of operating, using a combination of two electric motors, a gasoline ICE and a set of gears. The input split mode is used for launching the vehicle from a stop, driving at low speeds, and for towing, when more power is needed. The compound split mode is used for cruising at highway (faster) speeds when less power is needed. The hybrid system switches modes automatically. Both modes use a combination of electric motors and a gasoline engine.

By way of example, Saab has designed the Saab 9-3 BioPower Hybrid concept [28]. It is provided of GM ICE 2.0 L Turbo calibrated for E100 ethanol, but however enabled for any blend of ethanol and gasoline. Fig. (13) shows the layout in principle (a) and a picture of the two electrical motors mounted with two clutches (b), that offer four fixed gears. Similar concept architecture characterizes the vehicle models of GM, as example Saturn Vue Hybrid, Chevrolet Tahoe Hybrid and GMC Yukon Hybrid.

(a)

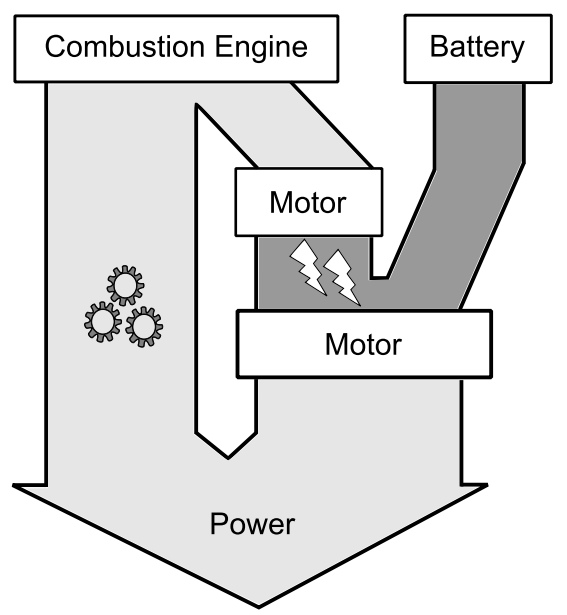

(b)

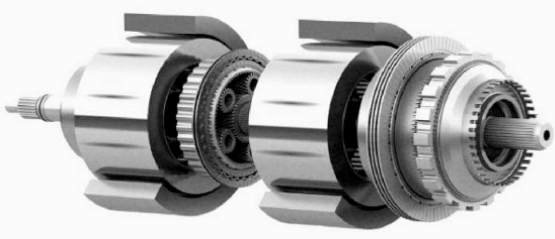

Fig. (13). General Motor two-mode system: (a) layout and energy flow, (b) the two electrical motors with gears.

Referring to [6] the vehicles specifications of HEVs sold in the U.S. market are reported in Table 2. It should be noted that all hybrid vehicles reported, with the exception of Chevy Silverado 2004, mount a NiMH battery. The electric motor size reported in Table 2 refers only to the front wheels drive motor.

\section{F. Light Truks}

Advantages according to the environmental concerns can be obtained thanks to hybrid electric bus or light trucks [4].
In these applications an induction machine (IM) is often used for the electrical propulsion. By way of example for trucks the Hino 4T Ranger HEV, and for bus both the General Motor (GM) Allison Hybrid system (parallel-hybrid) and the BAE system HybriDrive (series-hybrid) have an hybrid system provided of an IM.

Table 2. HEVs Specifications [6]

\begin{tabular}{|l|c|c|c|c|}
\hline \multirow{2}{*}{ Model } & \multicolumn{1}{c|}{ ICE } & El. mot. & \multicolumn{2}{c|}{ Battery } \\
\cline { 2 - 5 } & $(\boldsymbol{H P}) \boldsymbol{a t}(\mathbf{r p m})$ & $(\boldsymbol{k W})$ & $\boldsymbol{d c}(\boldsymbol{V})$ & $\boldsymbol{A h}$ \\
\hline \hline Chevy Silverado 2004 & 295 at 5200 & 14 & 36 & 70 \\
\hline Ford Escape 2005 & 133 at 6000 & 70 & 330 & 5.5 \\
\hline Honda Accord 2005 & 240 at 6250 & 12 & 144 & 6.0 \\
\hline Honda Civic 2006 & 110 at 6000 & 14.6 & 158.4 & 5.5 \\
\hline Lexus RX400h 2006 & 268 at 5600 & 123 & 288 & 6.5 \\
\hline Mazda Tribune 2008 & 133 at 6000 & 70 & 330 & - \\
\hline Nissan Altima 2007 & 158 at 5200 & 105 & 244.8 & 6.5 \\
\hline Saturn Vue 2007 & 170 at 6600 & 14.5 & 36 & 18.4 \\
\hline Toyota Camry 2007 & 147 at 6000 & 105 & 244.8 & 6.5 \\
\hline Toyota Highlander 2006 & 268 at 5600 & 123 & 288 & 6.5 \\
\hline Toyota Prius 2004 & 76 at 5000 & 50 & 201.6 & 6.5 \\
\hline
\end{tabular}

Other commercial light trucks that use PM electrical machine are the Eaton Hybrid system and the Nissan Condor (2003). The Eaton Hybrid system mount a 4.3 L 170 HP diesel ICE and a $44 \mathrm{~kW}$ PM brushless machine with a seriesparallel architecture. The maximum torque due to the PM motor is $420 \mathrm{Nm}$. The Li-ion battery has a nominal voltage of $340 \mathrm{~V}$ and a rated capacity of 7.2 Ah.

The Nissan Condor (prototype 2003) has a 6.93 L 204 HP diesel ICE and a $55 \mathrm{~kW}$ PM brushless machine with a parallel architecture. This latter light truck has an ultracapacitor storage system, whose characteristics are: nominal voltage of $346 \mathrm{~V}$, power of $60 \mathrm{~kW}$ and stored energy of $583 \mathrm{Wh}$.

\section{CONCLUSIONS}

In view of environmental protection, utilization of energy resources, and resource drains, as a kind of modern communication facilities, electrically operated vehicles are extensively paid close attention to in the whole world. HEVs are the nearest future on mass transportation, considering that recently also China auto manufacturers have launched their own plans to produce these vehicles.

Several commercial HEVs available in the global market, especially considering the U.S. and the European one, have already PM machine mounted for the electrical traction. Then the future of the HEVs seems to be certainly coupled to the use of the PM machine. In addition the PM machine technology on all topologies is not still completely mature and then future improvements could be achieved. Finally the HEVs could be in the future more electrical energy dependant, and at the limit all electrical vehicles, thanks to the next enhancements on energy storage system technology. 


\section{REFERENCES}

[1] Chan, C. C.; Wong, Y. S. The State Of The Art Of Electric Vehicles Technology, Proceedings of The $4^{\text {th }}$ International Power Electronics and Motion Control Conference, IPEMC 2004, Xi'an: China, 2004, vol. 1, pp. 46-57.

[2] Marei, M. I.; Samborsky, S. J.; Lambert, S. B.; Salama, M. M. A. On the Characterization of Ultracapacitor Banks Used for HEVs, Proceedings of the IEEE Vehicle Power and Propulsion Conference, VPPC '06, Windsor, UK, 2006, pp. 1-6.

[3] Beno, J.; Thompson, R.; Hebner, R. In Flywheel Batteries For Vehicles, Proceedings of the 2002 Workshop on Autonomous Underwater Vehicles, Piscataway, USA, 2002, pp. 99-101.

[4] Chan, C. C. In Global Sustainable Mobility and EV/HEV/FCEV Development in China \& Japan, Keynote Presentation of the IEEE Vehicle Power and Propulsion Conference, VPPC'06, Windsor, UK, 2006.

[5] Ehsani, M.; Gao, Y.; Gay, S.; Emadi, A. Modern Electric, Hybrid Electric, and Fuel Cell Vehilces, CRC Press: USA, 2005.

[6] U.S. Department of Energy (DOE) Energy Efficinecy and Renewable Energy (EERE) Office. http://www.eere.energy.gov (accessed September 1, 2008).

[7] Boldea, I.; Tutelea, L.; Pitic, C. I. PM-assisted reluctance synchronous motor/generator (PM-RSM) for mild hybrid vehicles: electromagnetic design. IEEE Trans. Ind. Appl., 2004, 40, 492-498.

[8] Bianchi, N.; Gieras, J. F. Electric motors for light traction, EPE J., 2004,vol. 12(1), 12-23.

[9] Parsa, L.; Toliyat, H. A. Fault-tolerant Interior-permanent-magnet Machines for Hybrid Electric Vehicle Applications. IEEE Trans. Vehicul. Technol., 2007, 56, 1546-1552.

[10] Parsa, L.; Goodarzi, A.; Toliyat, H. A. Five-Phase Interior Permanent Magnet Motor for Hybrid Electric Vehicle Application, Proceedings of the IEEE Vehicle Power and Propulsion Conference, VPPC'2005, Chicago: USA, 2005, pp. 631-637.

[11] Dutta, R.; Rahman, M. F. Design and Analysis of an Interior Permanent Magnet (IPM) Machine with Very Wide Constant Power Operation Range, Proceedings of the IEEE 32nd Annual Conference on Industrial Electronics, IECON'2006; Paris: France, 2006, pp. 1375-1380.

[12] Bianchi, N.; Bolognani, S. Parameters and volt-ampere ratings of a synchronous motor drive for flux-weakening applications, IEEE Trans. Power Electron., 1997, vol. 12(5), pp. 895-903.

[13] Bianchi, N.; Bolognani, S.; Chalmers, B. J. Salient-rotor PM synchronous motors for an extended flux-weakening operation range, IEEE Transact. Industry Appl., 2000, vol. 36(4), pp. 11181125.

[14] Zhu, Z. Q.; Howe, D. Electrical Machines and Drives for Electric, Hybrid, and Fuel Cell Vehicles, Proceedings of the IEEE, 2007, vol. 95(4), pp. 746-765.

[15] Ehsani, M.; Gao, Y.; Gay, S. Characterization of electric motor drives for traction applications, Proceedings of The $29^{\text {th }}$ Annual Conference of the IEEE Industrial Electronics Society, IECON'03; Raleigh: USA, 2003, vol. 1, pp. 891-896.

[16] El-Refaie, A. M.; Jahns, T.M. Impact of winding layer number and magnet type on synchronous surface PM machines designed for wide constant-power speed range operation. IEEE Trans. Energ. Conversion, 2008, vol. 23(1), pp. 53-60.

[17] Barcaro, M.; Bianchi, N.; Bolognani, S. Hybrid Electric Propulsion System Using Submersed SPM Machine, Proceedings of the 2008 International Conference on Ecelctrical Machine, ICEM'2008; Vilamoura: Portugal, 2008, pp. 1-6.

[18] Bianchi, N.; Pré, M. D.; Alberti, L.; Fornasiero, E. Theory and Design of Fractional-Slot PM Machines, ser. IEEE IAS Tutorial Course notes, IAS'2007 Annual Meeting, CLEUP editor (Padova, Italy); New Orleans: USA, 2007.

[19] Rahman, M. A. IPM Motor Drives for Hybrid Electric Vehicles, Proceedings of the Int. Aegean Conference on Electrical Machines and Power Electronics, ACEMP '07; Bodrum: Turkey, 2007, pp. 109-115.

[20] Dutta, R.; Rahman, M. F. In A segmented magnet interior permanent magnet machine with wide constant power range for application in hybrid vehicles, Proceedings of the IEEE Conference on Vehicle Power and Propulsion, VPPC'05; Chicago: USA, 2005.

[21] Barcaro, M.; Alberti, L.; Faggion, A.; Sgarbossa, L.; Pré, M. Dai; Bianchi, N.; Bolognani, S. IPM Machine Drive Design and Tests for an Integrated Starter-Alternator Application, Proceedings of The $43^{\text {rd }}$ IEEE IAS Annual Meeting Conference 2008; Edmonton: Canada, 2008.

[22] Rahman, K. M.; Patel, N. R.; Ward, T. G.; Nagashima, J. M.; Caricchi, F.; Crescimbini, F. Application of direct-drive wheel motor for fuel cell electric and hybrid electric vehicle propulsion system. IEEE Trans. Industry Appl., 2006, vol. 42(5), pp. 11851192.

[23] Kwon, T.-S.; Sul, S.-K.; Alberti, L.; Bianchi, N. In Design and Control of an Axial Flux Machine for a Wide Flux-weakening Operation Region, Proceedings of The 42nd IEEE Industry Applications Conference, IAS'2007, New Orleans, USA, Sept. 2327, 2007, pp. 2175-2182.

[24] Del Ferraro, L.; Caricchi, F.; Capponi, F. G.; De Donato, G. In Axial-Flux PM Starter/Alternator Machine with a Novel Mechanical Device for Extended Flux Weakening Capabilities, Proceedings of The $39^{\text {th }}$ IEE Industry Application Society Conference, IAS'2004, Seattle: USA, 2004, vol. 3, pp. 1413-1419.

[25] Asano, K.; Inaguma, Y.; Ohtani, H.; Sato, E.; Okamura, M.; Sasaki, S. In High Performance Motor Drive Technologies for Hybrid Vehicles, Proceedings of the Power Conversion Conference, PCC07, Nagoya, Japan, 2007, pp. 1584-1589.

[26] Matsumoto, S. In Advancement of Hybrid Vehicle Technology, Proceedings of the European Conference on Power Electronics and Applications, EPE'2005, Dresden, Germany, 2005, pp. 1-7.

[27] Yaegashi, T. In Challenge of Achieving Sustainable Mobility through Hybridization, Research and Development of Hybrid Vehicles in Japan and Sweden Seminarim, Göteborg, Sweden, 2006.

[28] Elliot, M. SAAB BioPowerHybrid Concept, Research and Development of Hybrid Vehicles in Japan and Sweden Seminarim, Göteborg, Sweden, 2006.

[29] U.S. Department of Energy (DOE) Energy Efficinecy and Renewable Energy (EERE) Office and U.S. Environmental Protection Agency, htpp://www.fueleconomy.gov (accessed September 1, 2008). 